\title{
ROLA KOLEGIALNOŚCI I SYNODALNOŚCI W BUDOWANIU WSPÓLNOTY EKLEZJALNEJ W ŚWIETLE POSOBOROWYCH DOKUMENTÓW KOŚCIOŁA
}

\section{THE ROLE OF COLLEGIALITY AND SYNODALITY IN BUILDING AN ECCLESIAL COMMUNITY IN THE LIGHT OF THE POST-CONCILIAR DOCUMENTS OF THE CHURCH}

Two concepts of collegiality and synodality regarding the Church took on great significance in the period after the Second Vatican Council, because both these concepts direct our attention to building a church community in a broad sense. This tendency to understand the Church in this way is due to the last popes, Saint Paul VI, St. John Paul II, Benedict XVI and Francis.

This new view of the Church as a community is led by both bishops and theologians studying this issue, who point to the great value of community from the highest level of the Church to parish communities.

This study show the great value of community for the whole Church.

Key words: collegiality, Collegiality of the Apostles, Saint Paul, synodality, Jerusalem Council, Second Vatican Council, Synod of Bishops, Second Extraordinary Synod of Bishops 1985, Diocesan synod, community - koinonia. 


\section{Wstęp}

Już u zarania głoszenia Królestwa Bożego przez Pana Jezusa i tworzenia struktur Kościoła, zostało przez Niego powołane Kolegium Apostołów odpowiedzialne za ewangelizację świata, albowiem im nakazal, aby szli na cały świat głosić ludziom Dobrą Nowinę. Pierwszą strukturą ewangelizacyjną a jednocześnie jako uporządkowany zespól głoszących Ewangelię Chrystusa było właśnie Kolegium Apostołów, które z czasem stało się podłożem instytucji zwanej kolegialnością w Kościele. W dalszym rozwoju Kościoła znaczenia nabierała synodalność. Synody miały szeroki wachlarz działalności, od synodów organizowanych dla jednego Kościoła lokalnego poczynając od synodów partykularnych jak przykładowo synod diecezjalny lub synod zespołu Kościołów partykularnych, wśród których rozróżnia się synod plenarny i synod prowincjalny, w sprawach dotyczących sprawowania władzy ustawodawczej ${ }^{1}$. O tych dwóch rzeczywistościach kościelnych: kolegialności i synodalności będzie mowa w niniejszym opracowaniu, ze wskazaniem na ich rolę budowania wspólnoty Kościoła.

\section{Kolegialność w Kościele}

Sobór Watykański II mówiąc o hierarchicznym ustroju Kościoła nawiązuje do działalności Pana Jezusa: „Pan Jezus, modląc się do Ojca i powołując tych, których zechciał, ustanowił Dwunastu, aby z Nim byli i aby posłani przez Niego głosili Królestwo Boże (zob. Mk 3, 13-19). A jednocześnie Apostołów tych (Łk 6,13), których:

Z nastaniem dnia przywołał swoich uczniów i wybrał spośród nich Dwunastu, których też nazwał Apostołami: Szymona, któremu nadał imię Piotr, i brata jego Andrzeja, Jakuba, Jana, Filipa, Bartłomieja, Mateusza, Tomasza, Jakuba, syna Alfeusza, Szymona z przydomkiem Gorliwy, Judę, syna Jakuba i Judasza Iskariotę, który stał się zdrajcą, ustanowił jako kolegium, czyli jako zespól, na którego czele postawił wybranego spośród nich Piotra².

Po Zmartwychwstaniu Jezusa Apostołowie, wspierani przez uczniów, szli na cały świat głosząc Ewangelię. Ich następcy, biskupi, czynili to samo niosąc wszelkim narodom Ewangelię Zbawienia. Sobór dalej naucza, że biskupi jako następcy Apostołów, poprzez „Święcenia biskupie, wraz z płynącą z nich misją uświęcania, przynoszą również funkcje nauczania i kierowania, które jednak ze swojej natury mogą być wykonywane tylko w hierarchicznej komunii z głową

\footnotetext{
$1 \quad$ M. Sitarz, Synod. I. W Kościele Rzymskokatolickim, [w:] Encyklopedia katolicka, t. 18, Lublin 2013, kol. 1339-1340.

2 KK 19.
} 
Kolegium i jego członkami”’3. Sobór poucza, odwołując się do ustanowienia Pańskiego, że jak św. Piotr i pozostali Apostołowie stanowili jedno Kolegium Apostolskie, w podobny sposób Biskup Rzymu, Następca Piotra i biskupi, następcy Apostołów, pozostają we wzajemnej łączności. Uwidoczniła się ta zasada w zwoływaniu synodów w celu rozstrzygania ważniejszych spraw dotyczących porządku prawnego i głoszenia Ewangelii. Zadania te wskazują zaś na kolegialny charakter Episkopatu. Potwierdzeniem tej zasady jest zwoływanie soborów powszechnych od starożytnych do obecnych czasów. Jednakże, co należy podkreślić, Kolegium, jako ciało biskupie posiadało (i posiada) władzę autorytatywną jedynie wtedy, gdy pozostaje w łączności z Biskupem Rzymu jako jego głową i gdy nienaruszony pozostaje jego prymat wobec wszystkich pasterzy i wiernych ${ }^{4}$.

Posoborowy Kodeks Prawa Kanonicznego potwierdza nauczanie Soboru Watykańskiego II o znaczeniu prawnym rozumienia Kolegium Biskupów. W kan. 336 stwierdza:

Kolegium Biskupów, którego głową jest Papież a członkami biskupi na mocy sakramentalnej konsekracji oraz hierarchicznej wspólnoty z głową Kolegium i z innymi członkami, i w którym trwa nieprzerwanie ciało apostolskie, razem ze swoją głową, a nigdy bez niej, stanowi również podmiot najwyższej i pełnej władzy nad całym Kościołem (KPK, kan. 336).

Te prawdy wynikające z nauczania Pana Jezusa, a później Soboru Watykańskiego II, potwierdza także Katechizm Kościoła Katolickiego z roku 1994 w punktach 552-553. Tenże Katechizm mówiąc o posłudze sakramentalnej Kościoła podkreśla jej charakter kolegialny wyrażający komunię braterską:

Do natury sakramentalnej posługi kościelnej należy także jej charakter kolegialny. Istotnie, od początku swojej misji Pan Jezus ustanawia Dwunastu, którzy byli zaczątkiem Nowego Izraela i początkiem świętej hierarchii. Razem wybrani, zostali także razem posłani, a ich braterska jedność będzie służyć komunii braterskiej wszystkich wiernych, będzie ona jakby odbiciem i świadectwem Osób Boskich (KKK 877).

W tych wypowiedziach podstawowych dokumentów Kościoła wyraźnie wybrzmiewa jedność całej hierarchii Kościoła, która nosi charakter wspólnotowy i tworzącą wspólnotę w Kościele.

\section{Synodalność w Kościele}

Powstanie instytucji Synodu datuje się już na II wiek po Chr. jako wyraz jedności pierwotnych wspólnot chrześcijańskich, jak też z potrzeby konsultacji

Tamże, 21.

Zob. tamże 22. 
w sprawach wiary ${ }^{5}$ 'Źródłosłów dla określenia pojęcia „synod” pochodzi z języka greckiego sin hodos - „iść razem”, „odbywać wspólną drogę”. W związku z rozwojem Kościoła i powstawaniem nowych biskupstw i tworzeniem się prowincji kościelnych, rodziła się potrzeba zwoływania synodów o różnym charakterze, przede wszystkim synodów diecezjalnych i prowincjonalnych, a od kilku dziesiątków lat także ogólnokościelnych.

Po Soborze Watykańskim II ogromnego znaczenia nabrał Synod Biskupów, co było zasługą papieża Pawła VI, który wydał motu proprio Apostolica sollicitudo dnia 15 września 1965 roku na wniosek Soboru Watykańskiego II, wskazując na prawa Papieża, ustanawiając instytucję Synodu Biskupów i zasady funkcjonowania tegoż Synodu. Od tego czasu Papieże zwołali już wiele Synodów Biskupich w Rzymie. Od czasu powołania instytucji Synodu Biskupów odbyło się ponad dwadzieścia synodów. Wyniki obrad były zwykle ujęte w ważne Adhortacje Papieży kierowane do całego Kościoła. Każdy z tych synodów miał znaczenie dla Kościoła, ale niektóre z nich są godne podkreślenia ich ważności i wyjątkowości. I tak Synod Biskupów zwołany przez papieża św. Pawła VI o ewangelizacji we współczesnym świecie z Adhortacją Evangelii Nuntiandi z roku 1974 roku; a także o katechizacji we współczesnym świecie, z podsumowaniem obrad Synodu Biskupów z roku 1977 w Adhortacji Catechesi tradendae.

Święty Jan Paweł II bardzo systematycznie zwoływał Synody Biskupów, które później owocowały cennymi Adhortacjami. Można tu wymienić kilka bardzo ważnych Adhortacji apostolskich, m.in. o zadaniach rodziny chrześcijańskiej we współczesnym świecie z roku 1980 z podsumowującą obrady Adhortacją Familiaris Consortio; II Nadzwyczajny Synod Biskupów w dwadzieścia lat od zakończenia Soboru Watykańskiego II z rewelacyjną relacją końcową; o powołaniu i misji świeckich w Kościele i w świecie z 1985 roku, z cenną Adhortacją Christifideles Laici datowaną na rok 1987, czy też Synod Biskupów na temat formacji kapłańskiej we współczesnym świecie z roku 1990 zwieńczony Adhortacją Pastores dabo vobis. Za pontyfikatu papieża Benedykta XVI także miało miejsce kilka ważnych spotkan Synodu Biskupów, z których warto wymienić m.in. Synod z roku 2005 o Eucharystii jako źródle i szczycie życia oraz misji Kościoła z Adhortacją Sacramentum Caritatis oraz o nowej ewangelizacji z roku 2012 z Adhortacją apostolską Evangelii Gaudium. Również papież Franciszek zwołał kilka Synodów Biskupich. Jeden z nich z roku 2015 jako przedmiot rozważań miał „Powołanie i misja rodziny we współczesnym świecie" z podsumowaniem Adhortacją Amoris laetitia. I ostatni, najnowszy

Zob. M. Sitarz, Synod. I. W Kościele Rzymskokatolickim, kol. 1339-1340. 
Synod Biskupów, kładł nacisk na troskę o poszanowanie przyrody, miał miejsce w Brazylii i został nazwany „Synodem Amazońskim”.

Po Soborze Watykańskim II wiele Kościołów lokalnych podjęło wysiłek przeprowadzania synodu diecezjalnego, aby przede wszystkim dostosować przepisy prawne regulujące funkcjonowanie diecezji do nowych soborowych wymagań i nowych uwarunkowań społecznych. Jeżeli weźmiemy pod uwagę dotychczasowe cele synodów diecezjalnych czy prowincjonalnych, kładące nacisk na regulacje prawne życia i działalności Kościoła lokalnego, to nie były one zbyt często zwoływane. Być może działo się to na skutek ogłoszenia doskonałego Kodeksu Prawa Kanonicznego, np. w Polsce z roku $1917^{6}$ czy posoborowego Kodeksu Prawa Kanonicznego wydanego w Polsce w roku 1994. Tymczasem zachęta i polecenie Soboru Watykańskiego II:

aby czcigodne instytucje Synodów i Soborów nabrały nowej mocy, a przez to stosowniej i skuteczniej dało się zaradzić wzrostowi wiary i zachowaniu karności w różnych Kościołach, stosownie do okoliczności czasu (DB 37).

Kodeks Prawa Kanonicznego promulgowany Konstytucją Apostolską Sacrae Disciplinae Leges z dnia 25 stycznia 1983 roku w księdze drugiej poświęconej „Ludowi Bożemu”, w części drugiej omawiającej „Hierarchiczny ustrój Kościoła" określa w kanonach 460-468, czym jest synod diecezjalny, komu służy, a jednocześnie podaje reguły jego przeprowadzenia. Zasadniczym celem synodu diecezjalnego ma być świadczenie pomocy i doradztwa biskupowi diecezjalnemu, któremu zostało powierzone kierowanie Kościołem lokalnym „dla dobra całej wspólnoty diecezjalnej” (kan. 460). Zwołanie i przeprowadzenie synodu jest wyłącznym prawem biskupa w jego kierowaniu powierzonym mu Kościołem; jest prawem, a jednocześnie wydarzeniem wyrażającym wspólnotę, która jest głęboko zakorzeniona w naturze Kościoła.

\section{Kolegialność i synodalność w budowaniu wspólnoty Kościoła}

Gdy mówimy o budowaniu wspólnoty Kościoła, warto się zastanowić, co rozumiemy pod terminem „wspólnota”. Jest wiele opracowań dotyczących wspólnoty, ale nas najbardziej interesują te z nowszych wypowiedzi, a które bazują na Relacji końcowej II Nadzwyczajnego Synodu Biskupów w Rzymie w 1985 roku. Relacja końcowa stwierdza:

Eklezjologia „komunii” (communio) jest ideą centralną i podstawową w dokumentach Soboru: Pojęcie koinonia - communio oparte na Piśmie św., obecne w Kościele starożytnym i w Kościołach Wschodnich aż po dziś dzień cieszy się wielkim

$6 \quad$ Kodeks Prawa Kanonicznego był wydany po łacinie, np. Codex iuris canonici iussu digestis Benedicti Papae XV, Freiburg in Br. 1918. 
uznaniem. Stąd Sobór Watykański II uczynił wiele, aby Kościół był wyraźniej rozumiany jako „komunia” i bardziej konkretnie jako „komunia” realizowany? „Relacja końcowa” wyjaśnia dalej, jak należy rozumieć komunię Kościoła: „U podstaw komunii chodzi o zjednoczenie z Bogiem przez Jezusa Chrystusa w Duchu Świętym. To zjednoczenie dokonuje się w Słowie Bożym i w sakramentach. Chrzest jest bramą i fundamentem Komunii Kościoła. Eucharystia jest źródłem i szczytem całego życia chrześcijańskiego. „Komunia” $z$ Ciałem Chrystusa w Eucharystii buduje wewnętrzne zjednoczenie („komunię”) wszystkich wiernych w Ciele Chrystusa, którym jest Kościól ${ }^{8}$.

Walter Kasper jako specjalny relator na II Nadzwyczajnym Synodzie (1985) porusza jeszcze inny, a bardzo ważny aspekt, który odnosi się do wspólnoty jako do źródła jedności Kościołów lokalnych ugruntowanej na celebrowaniu tej samej Eucharystii. Rozumienie jedności Kościoła jako jedności wspólnoty pozostawia szerokie ramy dla zaistnienia prawowitej wielości Kościołów lokalnych w obrębie większej struktury, ale w jednej wierze, przy sprawowaniu tych samych sakramentów i w spełnianiu tych samych funkcji. W tej odnowionej eklezjologii wspólnoty znajduje się miejsce na kolegialność, którą najlepiej można wyrazić słowami communio hierarchica. W pojęciu communio hierarchica urząd biskupa zostaje mocno związany z Kościołem powszechnym, a konkretnie we wspólnotę z Papieżem i biskupami. Według świadectwa Pisma Świętego oraz kościelnej tradycji, jedność jest zasadniczym określeniem istoty Kościoła, który dzięki tej jedności staje się una, sancta, catholica et apostolica ecclesia. Ten, omawiany przez Waltera Kaspera aspekt, stawia pewne warunki w realizacji jedności, a mianowicie: więcej kolegialności, więcej współodpowiedzialności, więcej informacji i przejrzystości w procesach decyzyjnych, aniżeli to się jeszcze dzieje w obecnym Kościele9.

Jednocześnie uczestnicy II Nadzwyczajnego Synodu dają wyraz temu rozumieniu Kościoła, że podczas trwania Synodu doznawali poczucia wspólnoty: „Synod ten dał nam doświadczyć «komunii» (communio) w jednym Duchu, w jednej wierze i nadziei oraz w jednym katolickim Kościele"10.

Również papież św. Jan Paweł II przygotował po II Nadzwyczajnym Synodzie Biskupów bardzo ważną dla rozumienia Kościoła jako wspólnoty Adhortację

7 Relacja końcowa, Dodatek do numeru 10-11-12 „L’Osservatore Romano” (wyd. polskie) z 1985 r., s. 5.

8 Tamże.

9 W. Kasper, Kirche als communio. Ueberlegungen zur ekkle4siologiuschen Leitidee des Zweiten Vatikanischen Konzils, [w:] Die bleibende Bedeutung des Zweiten Vatikanischen Konzils, red. F. Koenig, Duesseldorf 1986, s. 78 passim.

10 Relacja końcowa, Dodatek do nr 10-11-12 „L’Osservatore Romano” (wyd. polskie) 1985, s. 1. 
Christifideles Laici, w której nawiązuje do Relacji końcowej tegoż II Nadzwyczajnego Synodu Biskupów, mówiąc dosłownie:

Eklezjologia „komunii” (communio) jest ideą centralną i podstawową w dokumentach Soboru. Pojęcie Koinonia - communio, oparte na Piśmie Świętym, cieszyło się w Kościele starożytnym i cieszy się do dziś w Kościołach Wschodu wielką czcią. Stąd Sobór Watykański II uczynił wiele, aby Kościół był wyraźniej rozumiany jako „komunia” i bardziej konkretnie jako „komunia” urzeczywistniany ${ }^{11}$.

I dalej Papież mówi: „Rzeczywistość Kościoła-Komunii wiąże się nieodłącznie, więcej, zajmuje centralne miejsce wewnątrz owego misterium, którym jest Boży plan zbawienia ludzkości”12.

Podobnie synodalny końcowy dokument podkreśla, że pojęcie „komunii” jest oparte na Piśmie Świętym. Warto podkreślić, że poruszając temat „komunii”, wielu teologów powołuje się na opracowanie Friedricha Haucka w ThWNT ${ }^{13}$, który wskazuje na podstawowe znaczenia rodziny słów w Biblii; koinos, koinoo i pokrewne, a mianowicie: mieć udział w czymś, dawać (zapewniać) komuś udział w czymś, ale też jako kategoria podstawowa: koinonia - „wspólnota”. Zasadnicze znaczenie słowa koinonia - „mieć udział w czymś” - występuje przede wszystkim u św. Pawła, u którego otrzymuje to słowo treść religijną i oznacza wspólnotę wierzącego z Chrystusem i to zarówno jako udział w zbawczych dobrach, jak też udział we wspólnocie z innymi wierzącymi. Chrześcijanie są powołani do wspólnoty z Chrystusem: „Wierny jest Bóg, który powołał nas do wspólnoty (eis koinonian) z Synem swoim Jezusem Chrystusem, Panem naszym" (1 Kor 1,9). Jeżeli św. Paweł akcentuje słowa „z Synem swoim”, to wskazuje na to, że wspólnota przekracza nie tylko wzajemną zależność, ona wychodzi poza siebie i kieruje się do Boga. Zatem słowo koinonia oznacza stosunek wiernych do Jezusa Chrystusa w szerszym znaczeniu ${ }^{14}$. Pojęcie koinonia oznacza też udział w życiu Chrystusa: „Otóż, jeżeli umarliśmy razem z Chrystusem, wierzymy, że z Nim żyć będziemy" (Rz 6,8). Święty Paweł posługuje się słowem koinonia także na określenie wspólnoty powstałej na Ostatniej Wieczerzy. Udział w Chrystusie, który przeżywa się w wierze, jest urzeczywistniony w sakramencie: „Kielich

11 Jan Paweł II, Posynodalna Adhortacja Apostolska Christifideles Laici o powołaniu i misji świeckich w Kościele dwadzieścia lat po Soborze Watykańskim II, 19.

12 Tamże.

13 F. Hauck, koinos, [w:] G. Kittel, Theologisches Woerterbuch zum Neuen Testament, Bd 3, s. 796-810; por. J. Schattenmann, Gemeinschaft, [w:] Theologisches Begriffslexikon zum Neuen Testament, red. L. Coenen, B. Beyreuther, H. Bietenhard, Wuppertal 1967, s. 495-498.

14 K. Kertelge, Koinonia und Einheit der Kirche nach dem Neuen Testament, [w:] Communio Sanctorum. Festschrift fuer P. W. Scheele, red. J. Schreiner, K. Wittstadt, Wuerzburg 1988, s. 56. 
błogosławieństwa, który błogosławimy, czyż nie jest udziałem (koinonia) we Krwi Chrystusa? Chleb, który łamiemy, czyż nie jest udziałem (koinonia) w Ciele Chrystusa?" (1 Kor 10, 16). Chrześcijanie mają również udział w Duchu Świętym, a przez Ducha Świętego łączność z Chrystusem: „Łaska Pana Jezusa Chrystusa, miłość Boga i dar jedności (koinonia) w Duchu Świętym niech będą z wami wszystkimi" (2 Kor 13, 13). Na podstawie udziału w darach duchowych chrześcijanie łączą się pomiędzy sobą i tworzą dzięki temu w znaczeniu eklezjalnym wspólnotę Ducha Świętego ${ }^{15}$. Tak więc udział w Jezusie Chrystusie i w Duchu Świętym i w Jego darach, oznacza wspólny udział z innymi wierzącymi w Chrystusa, stąd koinonia ma znaczenie wybitnie eklezjalne.

Powyższe stwierdzenia i dociekania teologów opierają się na Słowie Bożym. Takim chyba najbardziej wymownym przykładem do tworzenia wspólnotowej postawy uczniów Chrystusa, jest mowa pożegnalna Pana Jezusa, zanotowana przez św. Jana Apostoła, w której Jezus zachęca Apostołów do trwania w jedności i we wspólnocie: „Przykazanie nowe daję wam, abyście się wzajemnie miłowali, tak jak Ja was umiłowałem, żebyście i wy tak się miłowali wzajemnie. Po tym wszyscy poznają, że jesteście uczniami moimi, jeśli będziecie się wzajemnie miłowali" (J 13, 34-35). Zachęta Pana Jezusa do trwania we wspólnocie i jedności była praktykowana przez pierwotny Kościół. Kościół staje się wspólnotą, jakiej pragnął sam Pan Jezus, gdy modlił się za uczniów: „Nie tylko za nimi proszę, ale i za tymi, którzy dzięki ich słowu będą wierzyć we Mnie, aby wszyscy stanowili jedno, jak Ty, Ojcze, we Mnie, a Ja w Tobie, aby i oni stanowili w Nas jedno, aby świat uwierzył, że Ty Mnie posłałeś” (J 17, 20-21). Po Wniebowstąpieniu Jezusa, jak notują Dzieje Apostolskie, wrócili Apostołowie z Góry Oliwnej do Jerozolimy i: „Wszyscy oni trwali jednomyślnie na modlitwie razem z niewiastami, z Maryją, Matką Jezusa, i z braćmi Jego" (Dz 1, 14). Ta jedność chrześcijan pierwotnego Kościoła pielęgnowana była nadal: „Trwali oni w nauce Apostołów i we wspólnocie (koinonia), w łamaniu chleba i w modlitwach. (...) Codziennie trwali jednomyślnie w świątyni, a łamiąc chleb po domach, spożywali posiłek w radości i prostocie serca" (Dz 2, 42; 46). Takie zachowania chrześcijan widoczne są na początku działania Kościoła. Przykładem takiej postawy osób odpowiedzialnych za ewangelizację świata jest tzw. Sobór Jerozolimski. Kolegium Apostołów jest tu wzorcowym przykładem jedności i wspólnoty pierwotnego chrześcijaństwa, przy wspólnym podejmowaniu decyzji. Gdy bowiem powstały nieporozumienia w Azji, zwłaszcza w Antiochii, na tle żądań przybyszów z Judei, aby przed udzieleniem chrztu dopiero co nawróconym poganom, najpierw dokonać obrzezania ich według zwyczaju Mojżeszowego, czemu sprzeciwiali się św. Paweł i św. Barnaba. Dla 
rozwiązania problemu wysłano $z$ Antiochii do Jerozolimy Pawła i Barnabę i kilku innych chrześcijan. Tam zebrali się Apostołowie i podjęli jednogłośnie decyzję:

Postanowiliśmy bowiem, Duch Święty i my, nie nakładać na was żadnego ciężaru, oprócz tego, co konieczne. Powstrzymajcie się od ofiar składanych bożkom, od krwi, od tego, co uduszone i od nierządu. Dobrze uczynicie, jeżeli powstrzymacie się od tego. Bywajcie zdrowi ( $\mathrm{Dz}$ 15, 28-29).

Tymczasem najważniejsze dokumenty Kościoła soborowego i posoborowego w rozważaniach dotyczących tematu synodu poruszają bardzo ważną sprawę, jaką w czasie posoborowym stał się termin communio, co nie jest nowością, bowiem od początków organizowania synodów bardzo pilnie pielęgnowano wspólnotę kościelną, rozwijano ją i zapobiegano ewentualnym wydarzeniom niesprzyjającym trwałości wspólnoty.

Sobór Watykański II stwierdza w Konstytucji Dogmatycznej o Kościele: „Chrystus, jedyny Pośrednik, ustanowił swój święty Kościól, tę wspólnotę wiary, nadziei i miłości tu na ziemi, jako widzialny organizm, nieustannie go też podtrzymuje, przez niego prawdę i laskę rozlewa na wszystkich” (KK 8). A dalej Sobór podkreśla, że Kościół będąc Mistycznym Ciałem Chrystusa, funkcjonuje jako widzialne zgromadzenie i wspólnota duchowa.

Ta prawda o jedności i wspólnocie Kościoła jest uwidoczniona w specjalnych instytucjach Kościoła, którymi są sobory powszechne, a od 1967 roku także w Synodzie Biskupów, jak też w synodach partykularnych, prowincjonalnych i diecezjalnych. Przykładem może służyć Synod Biskupów, który jako

zebranie biskupów, wybranych z różnych regionów świata, którzy gromadzą się w określonych terminach, ażeby umacniać ścisłą łączność między Biskupem Rzymu i biskupami. (...) Do ogólnych zadań Synodu Biskupów należą: podtrzymywanie więzi oraz żywej współpracy między papieżem i biskupami ${ }^{16}$.

Aby wspólnota synodalna, a w dalszej perspektywie wspólnota Kościoła lokalnego, mogła się umacniać i rozwijać, odnośnie zwłaszcza do synodu diecezjalnego, świadczy o tym KPK (kan. 468), gdy mówi o jego składzie. Na synod diecezjalny powinni być wezwani jako członkowie tegoż zgromadzenia: biskup koadiutor oraz biskupi pomocniczy, wikariusze generalni i wikariusze biskupi oraz wikariusz sądowy, kanonicy katedralni, członkowie Rady Kapłańskiej, wierni świeccy, także członkowie instytutów życia konsekrowanego, wybrani przez Radę Duszpasterską, rektor Seminarium Duchownego, dziekani i po jednym prezbiterze $z$ dekanatu, a także niektórzy przełożeni instytutów zakonnych i stowarzyszeń życia apostolskiego (KPK kan. 463). Ta lista uprawnionych członków synodu uzmysławia fakt, że w nich uwidacznia się cała wspólnota Kościoła lokalnego.

16 M. Sitarz, Synod Biskupów, [w:] Leksykon Teologii Pastoralnej, Lublin 2006, s. 823. 
Jak zaznaczono Kodeks Prawa Kanonicznego stwierdza, że celem synodu diecezjalnego jest realizowanie dobra całej wspólnoty diecezjalnej (kan. 460). To biskupowi ordynariuszowi powierzono prawo powołania synodu, który jest wydarzeniem wspólnotowym, wspólnota Kościoła zaś na każdym szczeblu jego działania jest głęboko zakorzeniona w samej naturze Kościoła.

Dlatego, aby wszelkie instytucje Kościoła, w naszym przypadku Kolegium Biskupów i kolegialność instytucjonalna i jako zasada funkcjonowania Kościoła w ogóle, a także, aby sobory i synody budowały wspólnotę, należy mieć stale przed oczyma istotną prawdę: Kościół jest wspólnotą i za jej budowanie na każdym szczeblu instytucji kościelnych, a także w jego najmniejszej organizacyjnie cząstce - parafii, aby była budowana przez wszystkich członków Kościoła: tych na wysokim szczeblu i tych wszystkich wiernych na najniższym szczeblu przynależności do Kościoła-wspólnoty.

Słowa kluczowe: kolegialność, Kolegium Apostołów, św. Paweł, synodalność, Sobór Jerozolimski, Sobór Watykański II, Synody Biskupów, II Nadzwyczajny Synod Biskupów 1985, synod diecezjalny, wspólnota - koinonia.

\section{Bibliografia:}

1. Codex Juris Canonici iussu digestis Benedicti Papae XV, Freiburgi i. Br.

2. Dekret o pasterskich zadaniach biskupów w Kościele Christus Dominus Soboru Watykańskiego II.

3. Hauck F., koinos, [w:] G. Kittel, Theologisches Woerterbuch zum Neuen Testament, Bd 3, s. 796-810.

4. Jan Paweł II, Posynodalna Adhortacja Apostolska Christifideles Laici o powołaniu i misji świeckich w Kościele i w świecie dwadzieścia lat po Soborze Watykańskim II

5. Kasper W., Kirche als communio. Ueberlegungen zur ekklesiologiuschen Leitidee des Zweiten Vatikanischen Konzils, [w:] Die bleibende Bedeutung des Zweiten Vatikanischen Konzils, red. F. Koenig, Duesseldorf 1986.

6. Katechizm Kościoła Katolickiego, Pallotinum 1994.

7. Kertelge K., Koinonia und Einheit der Kirche nach dem Neuen Testament, [w:] Communio Sanctorum. Festschrift fuer P. W. Scheele, red. J. Schreiner, K. Wittstadt, Wuerzburg 1988.

8. Kodeks Prawa Kanonicznego, Watykan 1984.

9. Konstytucja Dogmatyczna o Kościele Lumen Gentium Soboru Watykańskiego II.

10. Schattenmann J., Gemeinschaft, [w:] Theologisches Begriffslexikon zum Neuen Testament, red. L. Coenen, B. Beyreuther, H. Bietenhard, Wuppertal 1967.

11. Sitarz M., Synod Biskupów, [w:] Leksykon Teologii Pastoralnej, Lublin 2006, s. 823-826.

12. Sitarz M., Synod. I. W Kościele Rzymskokatolickim, [w:] Encyklopedia Katolicka, t. 18, Lublin 2013, kol. 1339-1340. 